\title{
Callosobruchus maculatus (Fab.) control by plant products in cowpea grains under storage: A review
}

\author{
A. Muhammad ${ }^{1 *}$, A. K. Bashir ${ }^{2}$ \\ ${ }^{1}$ Department of Crop Production and Protection, Federal University Dutsin-ma, Katsina State, \\ Nigeria \\ ${ }^{2}$ Department of Biological Sciences, Federal University Dutsin-ma, Katsina State, Nigeria
}

\begin{abstract}
The present review focuses on some major researches dealing with controlling Cowpea seed bruchid (CSB) due to Callosobruchus maculatus (Fab.) [Coleoptera: Bruchidae] by using some plant products. The objective of this review is to look in to the successes of the use of plant materials in the management of CSB especially in the tropics where bulk of the crop is cultivated and consumed. The review of available literature showed that, plants such as Neem, Azadirachta indica A. Juss; Garlic, Allium sativum (L.); West African pepper, Piper guineense Schumach; drum stick, Moringa oleifera Lam; African Basil, Ocimum gratissimum (L.); Moss plant; Barbula indica and Clausena anisata (Willd.) Hook has been used in CSB control. Available literatures showed that garlic, chilies and peppermint applied at the rate of $0.035-0.55 \mathrm{~g}$ significantly $(\mathrm{p} \leq 0.05)$ reduced oviposition, respectively compared to the control. Similarly, powdered flowers of $M$. oleifera applied at the rate of $0.5 \mathrm{~g}$ per $30 \mathrm{~g}$ of seeds caused mortality of CSB better than the control 8 hours after infestation. The use of C. anisata and Permethrin showed percentage mortality of cowpea bruchids was high using Permethrin but was not significantly $(\mathrm{p} \geq 0.05)$ better than Clausena leaf powder. Groundnut oil applied at $<4 \mathrm{mls} \mathrm{kg}^{-1}$ does not affect germination process of cowpea stored for up to 12 weeks. However, increasing rate of application decreases germination. The review clearly indicated that plant products have potentials of controlling CSB in stored cowpea as they are safe and free from residue. They are hereby encouraged.
\end{abstract}

Key words:

Plant products, management, Callosobruchus maculatus, cowpea
Received:

03 September 2017

Accepted:

20 December 2017

Published:

31 December 2017

${ }^{*}$ Corresponding Author:

A. Muhammad

Department of Crop

Production and

Protection, Federal

University Dutsin-ma,

Katsina State, Nigeria

Email:

amuhammad1@

fudutsinma.edu.ng

Citation:

Muhammad, A. and

Bashir, A. K. (2017).

Callosobrucbus maculatus

(Fab.) control by plant products in cowpea grains under storage: A review.

Journal of Medicinal

Botany, 1, 51-57. doi: 10.25081/jmb.2017.v1.897

\section{Introduction}

Cowpea (Vigna unguiculata (L.) Walp.) belongs to the family of crops Fabaceae, genus Vigna. It is known as black eye peas or southern peas and constitutes one of the most important food legumes in the tropics and sub-tropical countries (Yusuf et al., 2011). According to African Agricultural Technology Foundation - AATF (2011), cowpea is categorized as main grain legume which can be cultivated in tropical Africa. The crop is commonly consumed in the form of dry grains or young pods (Adenakan et al., 2013). Dried grains are prepared into moi-moi, Akara (Kosai) or eaten in combination with other crops such as rice, yam etc and can be used as forage also (Muhammad et al., 2017). Nearly 200 million people of Africa consume the crop (AATF, 2011). It is a cheap source of protein and thus serves as sources of plant protein to low income peasant farmers that cannot afford animal protein such as meat and fish (Yusuf et al., 2011; 
Ekeh et al., 2013). According to FAO-STAT (2012), Nigeria leads other countries with 2.5 million metric tons valued at $\$ 633,956,000$. FAO-STAT (2014) estimated that 5.7 million tons of dry cowpea grains were produced worldwide in 2013. Nigeria produced 2.5 million tons, making it the world's largest producer, followed by Niger and Mali. Callosobruchus maculatus (F.) is the major insect pest of cowpea in storage. Control of this pest was achieved using synthetic chemicals (Singh, 1985). However, due to hazards caused by these chemicals to plants, man and the environment, there has been the move to search for alternative using plant materials as biopesticide to control $C$. maculatus (Raja et al., 2001; Yusuf et al., 2011). The objective of this review is to look in to the successes of the use of plant materials in the management and control of CSB especially in the tropics where cowpea is cultivated and consumed.

\section{Cowpea insect pest complex}

Cowpea is a crop that is widely reported to be attacked by an array of insect pests and diseases. Taroesele et al. (2015); Adebiyi and Tedela (2012) reported that the insect problem is the major threat to this plant. Over 130 species of insects have been reported in cowpea cultivation (Ahmed et al., 2009).

\section{Losses due to insect pests attack on cowpea}

Losses in cowpea yield as reported by Ahmed et al. (2009) due to pests in northern Nigeria in all stages of plant growth. In general, losses due to pests attack or diseases can be as high as 90 percent. Similarly, Singh (1990) reported that CSB caused substantial amount of loss on stored cowpea in the tropics. Adebiyi and Tedela (2012) further stated that up to 100 per cent of seeds may be infested and damaged by CSB in 3-4 months of storage.

\section{Insect pests to cowpea}

Tiroesele et al. (2015) and Hamman et al. (2012) identified the following as some of the insects: Cowpea aphids, Aphis craccivora (Koch), Giant coreid bug, Anoplocnemis curvipes Stol (Hemiptera: Coreidae); Thrips, Megalurothrips sjostedti Tryb. (Thysanoptera: Thripidae); Flower or pollen beetle, Mylabris spp. Fab. (Coleoptera: Meloidae); Spiny Brown bug, Clavigralla tomentosicollis Germ. (Hemiptera: Coreidae);
Green stink bugs, Nezara viridula Linn. (Hemiptera: Pentatomidae) and Cowpea bruchid, Callosobruchus maculatus (F.) (Coleoptera: Bruchidae).

\section{Cowpea seed bruchid}

The cowpea weevil, $C$. maculatus is a major pest. Eggs are laid on cowpea pods or on avenues left by other biting and chewing insects (e.g. Mylabris spp). Adebiyi and Tedela (2012) stated that among the insect pests of stored cowpea seeds, C. maculatus is the most destructive. It is known as cowpea seed bruchid or pulse beetle.

Ratnasekera and Rajapkse (2012) reported CSB as the most serious pest in stored legumes in most of tropical countries, thus a serious pest of many crops. Ekeh et al. (2013) reported that CSB attack wide range of leguminous crops that include cowpea, chick pea, and many other legumes. Singh (1990) identified the larva of CSB as the damaging agent as it feeds inside the seeds.

\section{Control measures}

The use of chemical insecticides is the best way of controlling CSB. Ekeh et al. (2013) stated that fumigation is appropriate to control insects. Insecticides are having quick knock down action and are persistent, efficient and effective means of control. However, their use has some negative consequences for instance, Suleiman and Yusuf (2011) reported that, chemicals are unavailable, expensive, poses hazard to man and livestock. Adebiyi and Tedela (2013) reported health issues and resistance of pest against chemicals. Recent revelations have shown that synthetic insecticides were found to penetrate into grains and may be toxic (Adebiyi and Tedela, 2013). Ekeh et al. (2013) reported residues of methyl bromide one of the fumigant used in dis-infestation of stored foods exhibiting carcinogenic effects in rats.

\section{Examples of classical pesticide poisoning in Nigeria}

Vanguard Newspaper $\left(14^{\text {th }}\right.$ May, 2008) reported food poisoning believed due to ingestion of Moi-moi and beans in Bekwarra LGA of Rivers State. In 2011 some teachers were hospitalized and few lost their lives due to meal prepared at a workshop organized by Katsina State Ministry of Education (personal communication, November, 2015). Due to the above consequences, there is the need to develop 
a cheap, safe and easy method of protecting stored cowpea against CSB. The search for alternative methods of control that is economically feasible and environmentally friendly, safe to end-users was actively undertaken by scientist/researchers.

\section{Use of Plant Products as biopesticides}

Abdullahi (2011), Ratnaskera and Rajapkse (2012), Yusuf et al. (2011), Ekeh et al. (2013) and Adebiyi and Tedela (2012) independently reported the use of plant materials as biopesticides as alternative to use of chemicals. The use of plant derived biopesticides has the following advantages: plant products are more readily available, biodegradable and less toxic to non target organisms, selective in action and capable of retarding development of resistance (Rahman and Talukder, 2006). Abdullahi (2011) stated that plant materials are safe to biocontrol agents.

\section{Parts of the plants used}

Some examples of plant materials and the different parts used as biopesticides are shown in Table 1.

\section{Forms of Plant Materials Used as biopesticides-Powders}

Ahmed et al. (2009) reported the parts of the plant used include leaves, stems, seeds or roots. The plant parts would be washed and either air or shade dried, ground and sieved in to powder. The materials are grounded into powder using mortar and pestle or grounded electronically using blender or Culatt TZ grinder (Ahmed et al., 2009; Ogunwolu and Idowu, 1994). It will then be sieved using sieve of appropriate sizes. The resulting fine powder was used in dusting the surface of the cowpea. Application was based on weight/weight $(\mathrm{w} / \mathrm{w})$ basis. The powder properly coated the surface of the cowpea seeds before was stored. Tiroesele et al. (2015), Adenakan et al. (2013), Ekeh et al. (2013), Asawalam and Dioka (2012), Yusuf et al. (2011) and Ogunwolu and Idowu (1994) reported pesticidal properties of different parts of plant materials such as garlic, Chillies, Moringa, Dennitia tripetela, Curcuma longa (Turmeric), Neem and Clausena on CSB. Pirimiphos-methyl caused $\quad 100 \%$ control (mortality) of CSB but the performance was not significantly different ( $\mathrm{p} \geq 0.05$ ) with the leaf powder of Clausena anisata (76.8). The other powders of the plant materials were significantly $(\mathrm{P} \leq 0.05)$ better than the control (5.0). Similarly, the use of plant materials has significantly reduced the percentage seed perforation. The result showed that there was no significant difference $(\mathrm{p} \geq 0.05)$ between leaf powder $(2.0)$ and synthetic chemical (0.0). The highest percentage seed perforation was recorded in the control (96.7)

Table 1. Plant Products and Parts used as Biopesticides.

\begin{tabular}{lllll}
\hline Plant materials & Common name & Family & Parts used & Source \\
\hline Citrus sinensis O. & Sweet orange & Rutaceae & P & Yusuf et al. (2011) \\
Allium sativum L. & Garlic & Liliaceae & B & Ekeh et al. (2013) \\
Azadirachta indica (A. Juss) & Neem & Meliaceae & S, L & Ogunwolu and Idowu (1997) \\
Balanites aegyptiaca (L.) & Desert date & Balaniteceae & L & Abdullahi (2011) \\
Annona spp (L.) & Anona & Annonaceae & L & Ratnasekera and Rajpaske (2012) \\
Capsicum fructscens & Chilli pepper & Solanaceae & F & Yusuf et al. (2011) \\
Allium cepa (L.) & Onion & Solanaceae & B & Ahmed et al. 2009 \\
Clausena anisata H. - & - & Rutaceae & L, SB, RB & Ogunwolu et al. (2002) \\
Moringa oleifera Lam & Drum stick & Moringaceae & F, L, S, R & Adenakan et al. (2013) \\
Arachis hypogea L. & Groudnut & Leguminosae & O & Aliyu and Ahmed (2006) \\
Ocimum gratissimum L. & African basil & Lamiaceae & L & Ekeh et al. (2013) \\
\hline
\end{tabular}

Key: $\mathrm{P}=$ peel $; \mathrm{B}=$ bulb; $\mathrm{S}=$ seed $\mathrm{L}=$ leaves; $\mathrm{SB}=$ stem bark; $\mathrm{R}=$ root; $\mathrm{RB}=$ root bark $\mathrm{F}=$ flower; $\mathrm{O}=$ oil 


\section{Extracts}

Plant materials to be prepared were pulverized and the appropriate quantity soaked in water and the mixture was shaken and stirred thoroughly and applied directly or can be allowed to stand overnight, and the mixture is filtered over a muslin cloth (Ahmed et al., 2009 and Ahmed et al., 2007). The filtrate obtained formed the extract that was diluted with an appropriate quantity of water to form the spray solution (Oparaeke et al., 2005; Ahmed et al., 2009). Ogunwolu and Idowu (1997) reported that the crude extract is homogenized in methanol: water solvent. The suspension was evaporated, acidified and extracted with chloroform. This was either obtained using water or alcohol as aqueous or ethanol extract. The powder of plant materials were soaked in and left overnight. The mixture was shaken and filtered over clean muslin cloth and the filtrate is now used in biocontrol. Adebiyi and Tedela (2012), Ratnasekera and Rajapkse (2012), Abdullahi (2011), Rahman and Talukder (2006) and Ogunwolu et al. (2002) reported different pesticidal properties of some plants such as Moss plant, Neem, Desert date and Clausena on CSB. Adebiyi and Tedela (2012) showed the effect of extract in the control of CSB. The result showed that both the water and ethanol extract of Barbula indica were able to cause mortality of CSB significantly $(\mathrm{p} \geq 0.05)$ better than the control. The highest mortality was achieved with the application of $4 \mathrm{~g} 100^{-1} \mathrm{mls}$ (63.33 and 83.33) and the lowest mean CSB mortality was recorded in the control (3.33 and 16.67) for water and ethanol extract, respectively.

\section{Oils/volatiles oils}

Oils extracted from some plant materials are used in CSB control. Aliyu and Ahmed (2006) and Raja et al. (2001) reported the effect of groundnut oil and Mentha arvensis, M. spicata, $M$. piperata and Cymbopogon nardus respectively on CSB. The effect of groundnut oil on the germination process of cowpea seed stored for 12 weeks was reported. The germination process of the stored cowpea was not affected by the application of groundnut oil applied at the rate of $4 \mathrm{ml}$. However, when the rate of application was increased to $6 \mathrm{ml} \mathrm{kg}^{-1}$, the rate of germination decreased and at $8 \mathrm{ml} \mathrm{kg}^{-1}$ the rate was lowest. Therefore, storage of cowpea seeds intended for planting should not exceed $4 \mathrm{mls}$ $\mathrm{kg}^{-1}$. However, storage meant for consumption, the rate of $8 \mathrm{mls} \mathrm{kg}^{-1}$ will be appropriate.

\section{Mechanisms of activity of Botanicals Oviposition deterrent}

This is when the plant products prevent the insect from lying eggs on the stored product. This is exhibited by releasing fumes in to the surrounding that prevent mating and subsequent laying of eggs. Rahman and Talukder (2006) stated that when mixed with stored grains, leaf, bark, seed powder of plant material reduced oviposition. Good example of oviposition deterrent showed that the use of chillies, garlic and peppermint plant parts caused different level of deterrence to CSB. Chillies and garlic applied at the rate of $50 \mathrm{~g}$ per $500 \mathrm{~g}$ cowpea seeds greatly reduced oviposition relative to the control. The number of eggs laid on cowpea treated with chillies was not significantly ( $p \geq 0.05$ ) different with garlic but was significantly different with the control. Peppermint however recorded the highest number of eggs laid among the plant treatments but was still better than the control.

\section{Insecticidal}

Plant materials possessed active ingredients (a.i.) that have insecticidal properties. Neem contained Aradirachtin, Nimbin, Nimbidin, Selanin; P. guineense contained Guineense 1; Annona contained Annonacin; C. anisata contained Clausenol and Coumarins. The a.i. caused different toxicity properties to insects either by contact, stomach or through respiratory poison; Adenakan et al. (2013); Adebiyi and Tedela (2012) and Ogunwolu and Idowu (1994) reported toxicity properties of $C$. anisata, Moss plant and Moringa plants respectively on CSB. An example of toxic effect of plant materials was reported by Adenakan (2013). The findings showed that Moringa flower powder that was applied at the rate of $0.5 \mathrm{~g}$ per $30 \mathrm{~g}$ cowpea seeds caused insecticidal property in form of mortality. Actellic dust caused highest CSB mortality $10 \mathrm{hrs}$ after infestation. However, the same control was achieved with the application of leaf powder. All the treatments however caused significant control of CSB $24 \mathrm{hrs}$ after infestation. 


\section{Anti-feeding deterrent}

Anti-feeding is sometimes referred to as feeding deterrent. It was defined as the action of a chemical that inhibits feeding although does not kill the insect directly (Manukata, 1977). Saxena et al. (1988) defined anti-feedants as chemicals which retard or disrupt insect feeding by rendering the treated materials unattractive or unpalatable. In that situation, the pests get starved to death. This was when plant products prevented insect predation on stored products. The toxicity in effect may be by stomach poison.

\section{Repellency}

Plant products that were pungent or having irritating odour were used in insect repellency control. Takulder (2006) defined repellency as a chemical stimulus which causes the insects to make oriented movements away from the source of the stimulus. The use of plants such as Pine tree, Eucalyptus globules Labille; Rue, Ruta graveolens Linn. and Garlic, $A$. sativum as repellant had been reported (Ahmed et al., 2009). Talukder (2006) reported the use of essential oil of Artemisia annua L. as repellant against storage pests such as Tribolium castenum Herbst and Callosobruchus maculatus (L.). Some plants materials possessed repulsive odour which drive insect away. This phenomenon occured when fumes were released in to the vicinity, the odour will be perceived by the insect and will drive it away thereby dying due to hunger.

\section{Metamorphosis inhibition}

Plant products were used as biopesticides in arresting insect growth. The effect of growth regulatory plant products can be seen in several ways. There were molecules inhibiting metamorphosis. These compounds preventing completion of life cycle from taking place at the right time or force the insect to go through an early metamorphosis, so that development takes place at a time not favourable for the insect National Research Council (NRC) (1992). Others chemicals have been observed to alter hormones related to this function so that insects suffer malformation. Either, the insects were made sterile or were killed. NRC (1992) reported action of neem extract on some insect pests by way of disrupting their life cycle. The a.i. possessed by plant materials have the ability of inhibiting the life cycle of insects. A good example is Azadirachtin found in Neem. The a.i. prevents the insect from completing metamorphosis, or adults were malformed (NRC, 1992). Similarly, Adenakan et al. (2013) reported the efficacy of different parts of Moringa parts in reducing the development period of CSB. There was lower mean number of adults emerged at various seed treated with different parts of Moringa plant powders. The lowest number of adults that emerged was significantly different from the highest number that emerged in the control treatment.

\section{Limitations of the use of plant products as biopesticides}

One of the problems of usage of plant materials/products is the issue of standard dosage for universal application. Unlike synthetic chemicals that their applications were standard and universally or globally accepted. The active ingredients that are responsible for the toxic effect of plant products are easily denatured by solar radiation. Hence, many repeated application or requiring high dosage. Furthermore, use of plant materials often cumbersome. High volume of materials is needed for a unit of an area. However, synthetic chemicals are handy. For instance, Neem Foundation (2005) recommended the application of neem kernel powder at the rate of $5 \mathrm{~kg} \mathrm{ha}^{-1}$ while Uppercoat (Cypermethrin $250 \mathrm{~g}$ a.i. $\mathrm{l}^{-1}+$ Dimethoate $350 \mathrm{~g}$ a.i. $\mathrm{l}^{-1}$ ) was applied at the rate of 1.5 a.i. $\mathrm{L} \mathrm{ha}^{-1}$ Ogah (2013) for the control of Megalurothrips sjostedti and Maruca vitrata of Cowpea in Southeastern Nigeria. Tijjani et al. (2016) opined that due to their slow speed of action, biopesticides are often unsuitable if a pest outbreak is an immediate and became a threat to crops. Synthetic chemicals were however reported to have on the spot quick knockdown action and are persistent (Ahmed et al. 2009).

\section{Conclusion}

The review of available literature showed that use of different plant materials as powders or in form of extracts such as $A$. indica, $C$. anisata, chillies significantly reduced seed damage and deter oviposition of CSB on cowpea. The use of synthetic (such as pirimiphos-methyl) was however superior but was not significantly different with the plant materials. Similarly, byproducts of plant such as oil at lower rates can 
be use in preserving cowpea seed intended for planting. Control of $C$. maculatus on stored cowpea can equally be achieved using plant materials. Hence, synthetic chemicals should be used with caution due to health and environmental hazards.

\section{Recommendation}

The use of plant materials in cowpea seed bruchid control can therefore be recommended because they are safe and free from residue. Active awareness should adequately be undertaken to sensitized local farmers on how to use these products. Further research can be carried out in order to find out the toxicity effect of these plant materials on CSB.

\section{References}

Abdullahi, N. (2011). Studies on the efficacy of leaf extract of Balanites aegyptiaca on the oviposition and survival of immature stages (larvae and pupae) of Callosobruchus maculatus (F.) on stored cowpea seeds. Bayero Journal of Pure and Applied Sciences, 4(1): 40-43.

Adebiyi, A. O. and Tedela, P. O. (2012). Pesticidal effects of Barbula indica on Callosobruchus maculatus (Coleoptera: Bruchidae). Nature and Science, 10(9): 113-115.

Adenakan, M. O., Adejumo, A. O. Sodamola, M. O. and Ajetunmobi, T. (2013). Pesticidal effects of Moringa plant parts for the control of Bruchid beetle on cowpea seeds. International Journal of Applied Research and Technology, 2(6): 120-125.

African Agricultural Technology Foundation (AATF) (2011). Pod-borer Resistant Cowpea Project, www.aatf-africa. Accessed 18/01/2014.

Ahmed, B. I., I. Onu, B. I., Mudi, L and Aliyu M. (2007). Comparative efficacy of some selected plant derived biopesticides for the control of insect pests of cowpea (Vigna unguiculata (L.) Walp) in Katsina State, Nigeria, Korean Journal of Crop Sci. 52 (2): 183197.

Ahmed, B. I., Onu, I. and Mudi, L. (2009). Field Bioefficacy of Plant Extracts for the Control of Post Flowering Insect Pests of Cowpea, Vigna unguiculata (L.) Walp. in Nigeria. Journal of Biopesticides, 2(1):37-43.

Aliyu, M. and Ahmed, B. I. (2006). Comparative efficacy of different rates of groundnut oil for the control of cowpea weevils Callosobruchus maculatus (F.) in stored cowpea, (Vigna unguiculata (L.) Walp). Global Journal of Agricultural Sciences, 5(2): 123-126.

Asawalam, E. F. and Dioka, U. J. (2012). Evaluation of toxicity of Dennitia tripetala Baker F. and Curcuma longa L. rhizomes against cowpea seed bruchid, Callosobruchus maculatus (F.) Coleoptera: Bruchidae. Agricultural Science Research Journal. 2(6):308 311. Available online http://www.resjournals.com/ARJ

Ekeh, F. N., Onah, I. E. Atama, C. I. Ivoke, N. and Eyo, J. E. (2013). Effectiveness of botanical powders against Callosobruchus maculatus (Coleoptera: Bruchidae) in some stored leguminous grains under laboratory conditions. African Journal of Biotechnology, 12(12):1384-1391.

http//:www.academicjournals.org/AJB

Food and Agriculture Organization of the United Nation Statistics (FAO-STAT) (2012). Production Year Book, FAO Rome, Italy.

Food and Agriculture Organization of the United Nation Statistics (FAO-STAT) (2014). Production Year Book, FAO Rome, Italy

Hamman, S. I., Malgwi, A. M. and Micheal, C. G. (2012). Comparative efficacy of three biopesticides and a synthetic insecticide in controlling insect pests of cowpea (Vigna unguiculata L. Walp in Yola, Nigeria. Nigerian Journal of Entomology, 29:41-58.

Manukata, K. (1977). Insect antifeedants of Spodoptera litura in plants. In: P. A. Hedin (Ed). Pp 185-196. Host Plant Resistance to Pests. ACS Symposium Series No. 62, American Chemical Society, Washington.

Muhammad, A., Malgwi, A. M., Adamu, R. S. (2017). Maruca vitrata (Fabricius) [Lepidoptera: Pyralidae] larval population dynamics as affected by intra-row spacing, sowing dates and biopesticides on cowpea. Journal of Scientific Agriculture, 1: 352-364.

NRC (1992). NEEM: A Tree for Solving Global Problems. National Academy Press, Washington, DC. 141pp.

Ogah, E. O. (2013). Field Evaluation of Plant Extracts in the Management of Megalurothrips sjostedti and Maruca vitrata of Cowpea in 
Southeastern Nigeria. World Essays Journal 1 (1), 11-17. Available online at www. worldessaysj.com

Ogunwolu, E. O., Aku, A. A. Attah, J. and Igolli, J. O. (2002). Control of seed bruchid [Callosobruchus maculatus F.] infestation in cowpea [Vigna unguiculata (L.) Walp] with Clausena anisata Hook (Rutacea). Bioscience Research Communications, 14(2): 205-211.

Ogunwolu, O. and Idowu, O. (1994). Potential of powdered Zanthoxylum zanthoxyloides (Rutacea) root bark and Aradirachta indica (Meliaceae) seed for the control of the cowpea seed bruchid, Callosobruchus maculatus (Bruchidae) in Nigeria. Journal of Zoology, 108:521-528.

Oparaeke, A. M., Dike, M. C. and Amatobi, C. I. (2005). Field valuation of extracts of five Nigerian species for control of postflowering insect pests of cowpea, Vigna unguiculata (L.) Walp. Plant Protection Sciences 41:14-20.

Rahman, A. and Talukder, F. A. (2006). Bioefficacy of some plant derivatives that protect grain against the pulse beetle, Callosobruchus maculatus. Journal of Insect Science, 6(3):1-10. Available online: insectscience.org/6.03.

Raja, N., Albert, S. Ignacimuthu, S. and Dorn, S. (2001). Effect of plant volatile oils in protecting stored cowpea Vigna unguiculata (L.) Walpers against Callosobruchus maculatus (F.) (Coleoptera: Bruchidae) infestation. Journal of Stored Products Research, 37: 127-132.

Ratnasekera, D. and Rajapakse, R. (2012). The potential use of indigenous plant materials against Callosobruchus chinensis $\mathrm{L}$. and Callosobruchus maculatus L. (Coleoptera: Bruchidae) in stored legumes in Sri Lanka. Journal of Biopesticides, 5(supplementary): 8894.

Saxena, R. C., Jilliani, G. and Kareem, A. A. (1988). Effects of neem on stored grain insects. In: M. Jacobson (Eds.). pp 97-111. Focus on phytochemical pesticides, Volume 1, The Neem Tree, CRC press, Florida.

Singh, S. R. (1985). Insect Damaging Cowpea in Asia, In: Singh, S.R. and Rachie, K.O. (Eds.) Cowpea Research Production and Utilization. John Wiley and Sons, London, 247-250.
Singh, S. R. (1990). Insect pests of tropical food legumes, Chinchester, Wiley, 451pp.

Suleiman, M. and Yusuf, M. A. (2011). The potential of some plant powders as biopesticides against Sitophilus zeamais (Motsch.) (Coleoptera: Curculionidae) and Callosobruchus maculatus (F.) (Coleoptera: Bruchidae) on stored grains: a review. Bayero Journal of Pure and Applied Sciences, 4(1): 204207.

Talukder, F. A. (2006). Plant Products as potential stored-product insect management agents. A mini review. Emirate Journal Agric. Sci. 18(1):17-32.

Tijjani, A., Bashir, K. A., Mohammed, I. Muhammad, A., Gambo, A. and Habu, M. (2016). Biopesticides for pests control: a review. Journal of Biopesticides and Agriculture, 3 (1): $6-13$

Tiroesele, B., Thomas, K., \& Seketeme, S. (2014). Control of cowpea weevil, Callosobruchus maculatus (F.) (Coleoptera: Bruchidae), using natural plant products. Insects, 6(1), 77-84.

Yusuf, A. U., Dike, M. C., Adebitan, S. A. and Ahmed, B. I. (2011). Comparative efficacy of seven plant products on the cowpea bruchid, Callosobruchus maculatus development and damage. Journal of Biopesticides, 4(1): 19-26. 